\title{
How biomechanics can affect the endodontic treated teeth and their restorative procedures?
}

\section{Carlos José SOARES(a) \\ Monise de Paula RODRIGUES(a) \\ André Luis FARIA-E-SILVA(b) \\ Paulo Cesar Freitas SANTOS-FILHO(a) \\ Crisnicaw VERÍSSIMO(c) \\ Hyeon-Cheol KIM(d) \\ Antheunis VERSLUIS(e)}

\footnotetext{
(a) Universidade Federal de Uberlândia - UFU, Dental School, Department of Operative Dentistry and Dental Materials, Uberlândia, MG, Brazil.

(b) Universidade Federal de Sergipe, Dental School, Department of Dentistry, Aracaiú, SE, Brazil.

(c) Universidade Federal de Goiás - UFG, Department of Restorative Dentistry, School of Dentistry, Goiânia, GO, Brazil.

(d)Pusan National University, School of Dentistry, Department of Conservative Dentistry, Busan ,Busan, South Korea.

(e) University of Tennessee Health Science Center, College of Dentistry, Department of Bioscience Research, Memphis, TE, USA
}

Declaration of Interests: The authors certify that they have no commercial or associative interest that represents a conflict of interest in connection with the manuscript.

Corresponding Author:

Carlos José Soares

E-mail: carlosjsoares@ufu.br

https://doi.org/10.1590/1807-3107bor-2018.vol32.0076

Submitted: May 12, 2018

Accepted for publication: May 29, 2018

Last revision: June 13, 2018

\begin{abstract}
Endodontic treatment is a common dental procedure used for treating teeth which the pulp tissue has become irreversibly inflamed or necrotic as a result of the carious process or dental trauma. This procedure which involves mechanical and chemical preparation of root canal may affect several mechanical and physical properties of the tooth structure. The endodontic treatment can also influence the longevity of the rehabilitation of endodontically treated teeth and biomechanics during the oral function. For restoring endodontically treated teeth several factor and clinical decisions should be observed. The decision of the fiberglass post usage and the restorative materials are related to several factors such as the quantity and quality of remaining dental structure, presence of ferrule, post cementation length and final coronal restoration. In this review, the authors will address the effect of the endodontic treatment procedures on canal shape and mechanical properties of a tooth, and also discuss the parameters and the biomechanical principles of root canal treated teeth.
\end{abstract}

Keywords: Tooth, Nonvital; Root Canal Therapy; Biomechanical Phenomena.

\section{Introduction}

The primary function of the human dentition is the preparation and processing of food through a biomechanical process of biting and chewing. This process is based on the transfer of masticatory forces, mediated through the teeth. ${ }^{1}$ The synergism of enamel, coronal dentin and root dentin creates an integrated organ that is capable of supporting high masticatory stresses. Root dentin is an important structure to integrate the dentition with muscle-bone support. Human root dentin has higher flexural strength and more significant inelastic deformation than coronal dentin. ${ }^{2}$ Understanding the mechanical behavior of dentin and the detailed relations to the dentinal structure provides insight into the design strategies to recover tooth functions and helps to improve dental restoration techniques, preventing catastrophic failures. ${ }^{2}$

When the tooth crown is structurally compromised by caries or defective restorations, root canal treatment may be necessary to maintain tooth integrity and to provide stability for coronal rehabilitation. Endodontic treatment is mainly purposed to remove the infected tissues and 
microorganisms from the root canal system to control the periapical inflammatory responses and infections. Endodontic treatment is a predictable therapy with a success rate up to $97 \% .{ }^{3}$ However, it was reported that some of the failure cases of endodontically treated teeth are resulted from nonmicrobial factors as well as biological factors. ${ }^{4}$ Dentinal collagen makes a considerable contribution to the mechanical properties of dentin. ${ }^{5}$ Changes in these collagen fibril crosslinks may contribute to the so-called "brittleness" of endodontic treated teeth. ${ }^{6}$ Loss of pulp vitality also influence moisture content of dentin and iatrogenic factors associated with various operative procedures may contribute to the fracture of endodontically treated teeth, although most of these risks are controllable. ${ }^{7}$

Endodontically treated teeth are structurally compromised by caries, endodontic access, present alterations in mechanical, chemical, and physical properties. ${ }^{7,9}$ For restoring endodontic treated teeth the first question frequently observed is: "what material is more appropriated?" and the followed question is: "which technique, direct or indirect restoration, is better for restoring endodontic treated teeth?" and also, "Is necessary to recover cusp structure?". These questions were for long time responded based frequently in personal option. Nowadays, the evidences support that the principal aspect is to use adhesive technique for creating a unique and integrated body, involving all the materials and interfaces..$^{10,11,12,13}$ Amalgam should severely avoid to restored endodontic treated, because this material only fill cavity but does not restore the stress/strain behavior., ${ }^{1,10,11}$

Severally structurally compromised endodontic treated teeth often require a post to retain a coronal restoration. Compared with metal posts, fiberreinforced resin posts are the better option for root canal treated teeth. ${ }^{9}$ The major advantage of the fiberreinforced posts is they have an elastic modulus that is similar to dentin, which results in a more even distribution of occlusal loads through the root. ${ }^{14,15,16}$ The stress/strain distribution in root canal treated teeth restored with fiber-reinforced resin posts depends on several factors. Teeth with extensive caries, pulp involvement and loss of structural integrity can result in pain and reduce mastication due to natural adaptation. Endodontic treatment followed by direct composite restoration was an effective method to reestablish oral biomechanical performance. ${ }^{17,18}$

The performance of endodontic treated teeth is strongly related to the biomechanics events involved during all the phases of the endodontic treatment ${ }^{19,20}$ and also during the restorative procedure of these teeth. ${ }^{9,20}$ Therefore, this review article will focus on biomechanics effect involved on tooth structurers influenced by endodontic treatment, on the root instrumentation and obturation, on the restorative procedure used, and their consequences to the clinical longevity of the restored endodontic treated teeth.

\section{Dentin alterations related to endodontic procedures and endodontic materials}

The dentine is a very complex organic structure. This structure is a composed by $70 \%$ of inorganic material, $18 \%$ organic matrix and $12 \%$ of water by weight. ${ }^{21}$ The dentin is covered by the enamel which is the hardest tissue in the human body. The enamel has a high elastic modulus compared to the dentin..$^{22}$ The collagen matrix contributes to a lower elastic modulus compared to the enamel. The dentin is perfectly bonded to the enamel by the dentin-enamel junction and creates a perfect integration for the masticatory load and stress distribution for the periodontal ligament and bone. ${ }^{23}$ The endodontic treatment is responsible for a several dentin microstructural changes and mechanical properties alterations. Studies have shown that postendodontic tooth fractures might occur because of the tooth loss cause during the endodontic access cavity preparation; root canal instrumentation; root canal filling technique; inadequate post space preparation and selection. Tang et al.7 in 2010, showed trough a literature review that all this factors are related to potential tooth fractures after the endodontic treatment.

During the endodontic treatment, the root canal irrigation is crucial for the endodontic treatment clinical success. The intracanal irrigants are used to eliminate the microorganisms, pulp remnants and the smear layer created during the root canal instrumentation. However, despite of the advantages of the irrigants they may be related to physical 
and mechanical properties alterations of the dentin when used for a prolonged period or high concentrations. Sodium hypochlorite $(\mathrm{NaOCl})$ and the ethylenediaminetetraacetic acid (EDTA) are common during the mechanical-chemical preparation of the root canal. Studies showed that the endodontic irrigant solutions can affect the microhardness of the root dentin. ${ }^{24}$ The literature shows that irrigation with either $\mathrm{H}_{2} \mathrm{O}_{2} / \mathrm{NaOCl}$ or EDTA can decreased the microhardness value of root dentin. These irrigants can also change the mechanical properties of the dentin such as flexural strength and elastic modulus. Some investigations evaluated the effect of $\mathrm{NaOCl}$ $(3 \%, 5 \%)$ and saturated calcium hydroxide $\left(\mathrm{Ca}(\mathrm{OH})_{2}\right)$ solutions on the flexural strength and elastic modulus of dentin using three-point bending test. The results showed that $\mathrm{NaOCl}$ reduced both elastic modulus and flexural strength and the saturated $\mathrm{Ca}(\mathrm{OH})_{2}$ reduced the flexural strength but not the elastic modulus of dentin. ${ }^{5}$ A recent study evaluated the effects of several decalcifying agents on the chemical composition of the dentine using attenuated total reflectance in Fourier transform infrared spectroscopy (ATR-FTIR) ${ }^{25}$ Results showed that the etidronic acid and tetrasodium EDTA caused minor whilst trisodium EDTA and peracetic caused greater demineralization of dentine. The authors also found that the sodium hypochlorite degraded the dentin organic matrix more rapidly when exposed to dentine. However, the combination of $\mathrm{NaOCl}$ and decalcifying agents can be used to create dentine surfaces with varying compositions for interaction with endodontic sealers. Physical properties changes occur mainly because of the removal of the collagen matrix and inorganic components of the root dentin during the instrumentation procedure. ${ }^{25}$ Clinicians should be very careful during root canal treatment that the irrigants should be completely removed from the canal before root filling procedure. The endodontic irrigants can also affect adhesive restorative procedures such as the fiber post luting. There are some investigations that the EDTA and the sodium hypochlorite can the best option regarding the bond strength between the resin cement and the dentine. ${ }^{26}$ For a better result, the remnants of the endodontic irrigants should be fully removed after the post space preparation.

\section{Mechanical effect and performance of endodontic files}

Clinicians need to use root endodontic files to shape for easy and efficient cleaning and obturation. To remove infected tissues including pulp and root canal dentin, mechanical forces are mandatory during the use of the instruments. These mechanical forces by the endodontic files always have some reaction forces to the root dentin and structure. ${ }^{27}$ Different instrument systems may have different forces and consequent risk or incidence to induce the dentinal damage or apical micro cracks according to the instruments geometries, sizes, or alloys..$^{28,29}$ Root canal preparation procedures have been reported to increase the risk of root fracture and crack formation by reducing root dentin integrity or creating defects inside root canals that may act as stress concentrations or crack initiation sites. ${ }^{29,30,31}$

Nickel-titanium (NiTi) endodontic instruments have brought convenience and efficiency to root canal shaping, which reduces procedural errors. ${ }^{31,32}$ Most clinicians prefer these systems because of their advantages such as improved cutting efficiency, time saving and reduced postoperative discomfort. ${ }^{30,32,33}$ During the instrumentation by using NiTi files, a root canal is cut and enlarged by the contact between instruments and root dentin walls. The numerous momentary contacts by the fast moving (usually rotating) speed over $300 \mathrm{rpm}$ between instrument and canal wall create stress concentrations in dentin and may induce dentinal defects and microcracks or craze lines. ${ }^{27,29,34}$ Root canal preparation alone significantly weakened roots, especially when the working length is longer than optimal, and may create apical root cracks. ${ }^{31}$ Thus, the screw-in forces by some active rotary NiTi files, especially used by inexperienced operators, may have a higher chance to go over the apical foramen and may increase the risk of apical crack formation. ${ }^{35,36}$

Dentinal damages such as craze lines and partial cracks in teeth were prepared with several brands of NiTi rotary instruments, although no defect was observed in teeth prepared with manual stainless steel files. ${ }^{28}$ This type of defects would be associated with increased susceptibility of vertical root fracture (VRF) because functional loads or stresses from the repeated occlusal forces after restoration can be 
amplified at the tip of those defects and initiate or propagate into VRF. $29,31,37$ VRF is usually diagnosed a few years after the endodontic and restorative treatments are completed. ${ }^{38,39} \mathrm{VRF}$ is one of the most disappointing complications of root canal treatment, which may result in a tooth extraction. ${ }^{29}$

Stresses in root dentin during instrumentation by various NiTi instruments have been studied ${ }^{27,29}$ investigated the potential relationship between $\mathrm{NiTi}$ instrument design and the incidence of vertical root fracture and crack formation by using finite element analysis. This study compared stresses generated in apical root dentin during rotary instrumentation in a curved canal with NiTi files featuring different cross sections and shaft geometries. It was shown that during root canal instrumentation, under certain clinical conditions (for example, in a severely curved canal), file design (with a big taper) and/or its mechanical properties (stiffness or flexibility) may generate stresses that exceed the tensile strength of dentin. On the other hand, some NiTi instrument systems for coronal canal flaring, which are used in early stage of root canal preparations, were reported to have lower rates of crack formation than those found with Gate-Glidden drills. ${ }^{40}$

In 2008, reciprocating movement for the use of NiTi instrument systems instead of continuous rotation was suggested. ${ }^{41}$ Many articles have since been published about reciprocating NiTi instrument systems, which are used in a single file technique for clinical convenience and efficiency. ${ }^{42,43}$ The conclusions regarding apical crack formation in many of these articles are contradictory. ${ }^{44,45,46,47}$ Although root canal preparation with both rotary and reciprocating instruments resulted in dentinal defects, at the apical level of the canals, the reciprocating files resulted in significantly more incomplete dentinal cracks than full-sequence rotary systems. ${ }^{44}$ On the other hand, ProTaper rotary files (Dentsply Sirona) have significantly more microcracks than ProTaper hand files and WaveOne Primary reciprocating files (Dentsply Sirona) ${ }^{45,48}$ reported that, with regard to the potential risk of root cracks from the file system, WaveOne instruments induced the least number of cracks and exhibited the greatest resistance to fracture compared with ProTaper files whether used in reciprocating or rotating motions. They concluded that the M-alloy from which the reciprocating instruments manufactured was a more important factor for the dentin damaging potential than the motion of instrumentation..$^{45}$ Therefore, no causal relationship could be concluded between dentinal microcrack formation and root canal preparation procedures with the reciprocating systems. ${ }^{46,47}$ While the WaveOne and Reciproc reciprocating instruments were made of M-wire, recently introduced WaveOne Gold and Reciproc Blue systems are made of heat treated Goldwire and Blue-wire respectively and they have much softer characteristics than the M-wire and conventional NiTi alloy. The heat treatment for these Gold and Blue NiTi alloys has controlled-memory effect in the room temperature and thus they have reduced reaction forces during their rotary or reciprocating movement. ${ }^{49,50}$

In another unique development, the design of a SelfAdjusting file (SAF) - an instrument without an internal core and with a mesh-like structure - may produce minimal stress concentrations in the apical root dentin during shaping of the curved root canal. SAF system may have higher chance of preservation of root dentin integrity with a reduced risk of dentinal defects and apical root cracking ${ }^{51,52,53}$ reported that the SAF system may generate only one tenth of the forces generated by the conventional rotary NiTi files (Figure 1).

In addition to the different kinetic movements such as reciprocating and ocillation of the reciprocating instruments and SAF, other innovative shaping instruments were developed recently. The XP-endo Shaper (FKG), XP-endo Finisher and TRUShape 3D were introduced as less invasive files to clean the irregular canal geometries better and preserve root dentin. They actually have reduced contact points to the canal wall due to their irregular shape of file shaft and thus make it possible to treat root canals with highly complex morphologies, from the narrowest to the largest, and from the straightest to the most severely curved canals. They were claimed as truly innovative files which can be used to radically simplify endodontic sequences and provide superior overall shaping compared to conventional ISO rotary files. ${ }^{54,55,56}$ Although the precise effect of each shaping procedure may still be contested, it is well accepted that stress levels during shaping and the susceptibility to apical root cracks after shaping vary with instrument design. ${ }^{57}$ 
A

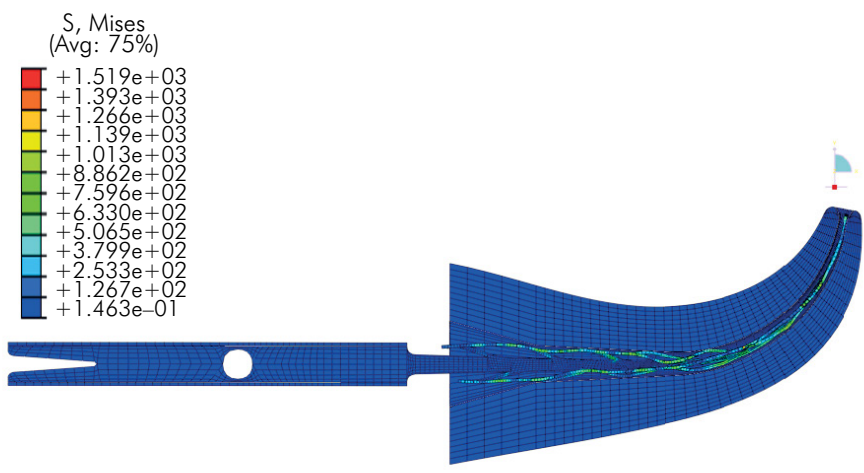

B

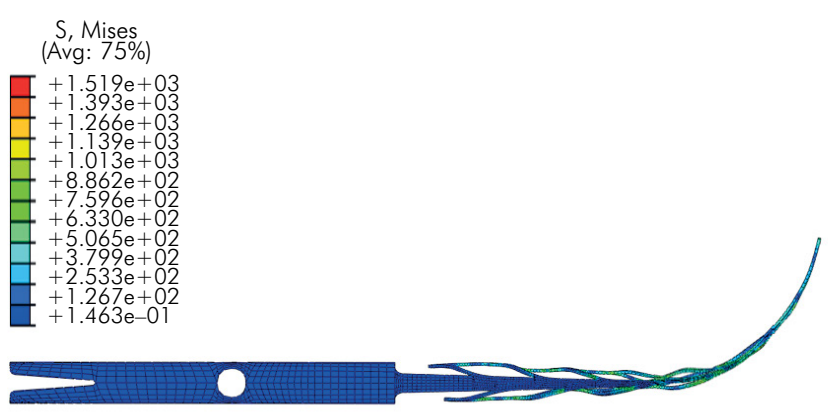

C

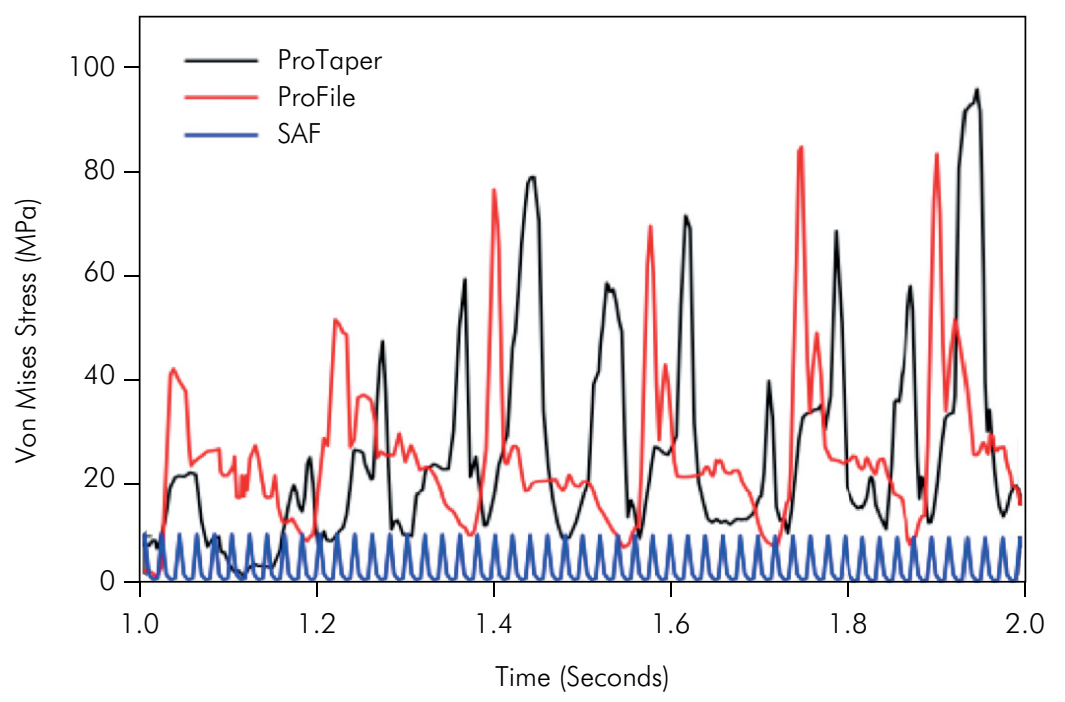

Figure 1. A. Self-Adjusting File (SFA) working in a simulated root canal (Finite element model simulation). B. Final element model of SAF without canal constriction shows the shape adjusted. C. SAF shows lower stress generation comparing with conventional rotary files ${ }^{53}$.

Comparing primary root canal treatment with retreatment, retreatment procedures may result in more defects than initial treatments. ${ }^{58}$ Therefore, it was suggested that when assessing the outcomes of endodontic retreatment, substantial damage to the root canal walls should be considered. Practitioners that are aware of controllable and uncontrollable risks during dental treatments may beable to reduce potential tooth fractures. ${ }^{7,77}$ 


\section{Restorative materials and the capacity to recover tooth integrity}

The endodontic treatment finished after a perfect tooth restoration. During the endodontic therapy, the tooth should receive a temporary restauration with glass ionomer cement or composite resin. ${ }^{20}$ The time between the root canal filling and restorative coronal reconstruction should be the shorter possible to avoid the root canal contamination.

The coronal reconstruction of endodontically treated tooth must recover the biomechanical performance as similarly as possible to the intact tooth. The structural resistance is related to appropriate retention and adhesive integration between root dentin, core reconstruction and final restoration, forming a unique and integrated complex. Direct restorative materials, mainly composite resin has proven to be enough to reconstitute the coronal part that will be the support for a crown, only when necessary. ${ }^{12}$ The use of a 1-2 mm of glass ionomer cement to cover the root canal obturation is recommended to reduce the stress inside the pulp chamber and furcation area of posterior teeth. ${ }^{59}$ The use of some bulk fill composite resin may reduce the cusp deflexion and the stress concentration on the weakened regions. ${ }^{60}$ However, it is important to highlighted that this performance is material dependent. The use of amalgam for restoring posterior endodontic treated teeth is not recommended. Amalgam is a material that fill cavity but it does not restore the tooth integrity.

The teeth endodontically-treated with progressive loss of tooth structures from extensive caries may have an impact on the masticatory process, result in pain and reduce mastication and higher stress concentration on tooth remaining (Figure 2). The endodontic treatment followed by direct restoration with bulk-fill composite resin improve the biting force and promote homogeneous stress distribution. ${ }^{17}$

Irrespective of the material selection the bonding integration between restorative materials to tooth structure remaining is fundamental for adequate stress/strain distribution. Nowadays all the most of the restorative materials and adhesive systems are light activated. The correct selection of the dental light-curing unit (LCU) and how it is used is an essential part of the process of photocuring an adhesive system, composite resin, resin cement involved on the restorative procedure of endodontic treated teeth. ${ }^{61}$ The light attenuation deep areas of the root canals may compromise the polymerization of the resin cement used for fixing fiber glass post. ${ }^{62}$ The use of dual cure resin cement is essential for achieve adequate curing and integration between post-resin cement and root dentin. When curing resin cement for fiberglass post fixation the best results that were found was when photoactivation is delayed for

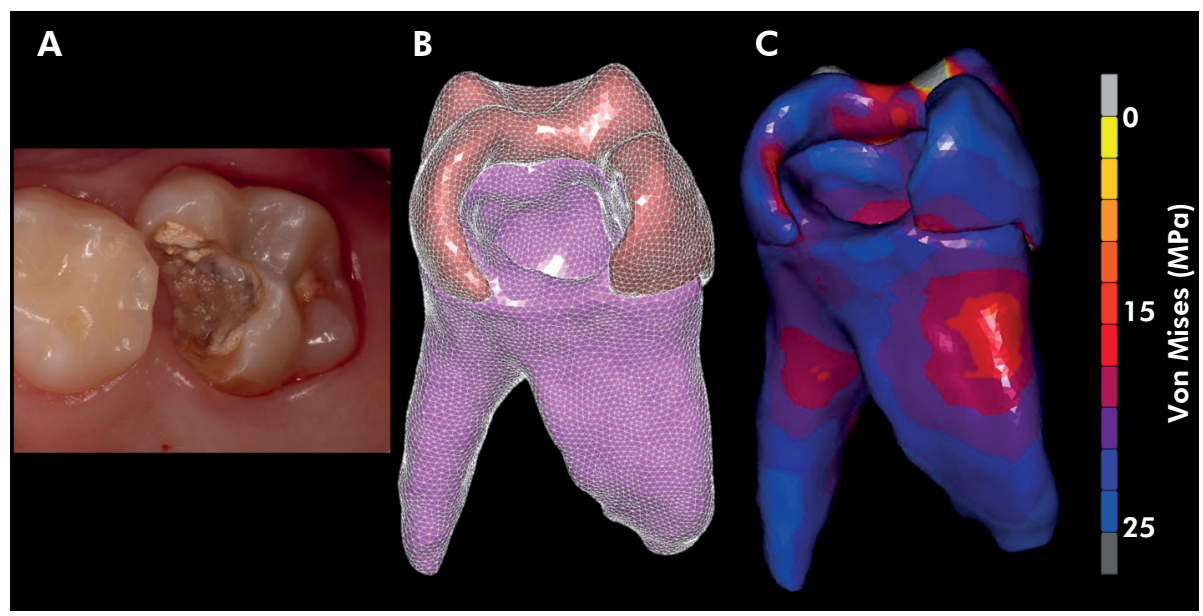

Figure 2. A. Clinical pictures of caries affected molar tooth; B. corresponding patient-specific finite element models. C. Modified von Mises stress concentration on occlusal enamel without dentin support and also on the pulp floor. 
five minutes after the manipulation of the resin cements, which is clinically feasible. Shrinkage stress was higher with immediate photoactivation for all resin cements and resulted in higher shrinkage stresses mainly in the coronal third where debonding between resin cement and root dentin account for most failures. ${ }^{59}$ The use of LCU positioned correctly over the restoration and the light shots covering the entire extension of the direct or indirect restoration is also fundamental for good polymerization process. The time recommended for light curing different materials should be carefully followed and the LCU should maintained stable to maintain the light intensity regular. Using protective eyewear allows the user to have both hands free to manipulate the instruments and materials so that they can focus their attention on the tooth to which the light is directed, and deliver the intended amount of light to the resin. . $1,63^{-63}$

\section{Fiber post - Factors that influence the selection and the effect on the biomechanical performance}

Fiber posts have been widely used and are gradually replacing the traditional metallic cast post and cores and prefabricated metal posts. ${ }^{8}$ In the last decade, several types of post systems have been proposed for the rehabilitation of the endodontically treated teeth with extensively coronal lost. ${ }^{8}$ Among the nonmetal posts, epoxy resin posts reinforced with carbon fibers, epoxy or methacrylate resin posts reinforced with quartz or glass fibers, zirconia posts, and polyethylene fiber-reinforced posts are used. Fiber glass posts are the non-metallic posts are mostly used with clinical success. However, the longevity and the clinical success of the endodontically treated teeth rehabilitated with fiber posts depends of several factors such as: a) Post selection and design; b) Post length; c) Post diameter; s) quantity and quality of the remaining coronal dentin (ferrule effect).

a. Post selection and design

Cast metal post and cores have high elastic modulus and have been associated with high incidence of unfavorable root fractures. In response to the need for esthetic materials and mechanical properties similar to root dentin, nonmetal posts were developed. Clinical and laboratory studies have shown that fiber-reinforced resin ('glass fiber') posts are an excellent option for the rehabilitation of root filled teeth instead of metal posts. ${ }^{9,64}$ Glass fiber posts have similar values for the flexural strenght and flexural modulus compared to quartz fiber posts. The fiber glass post designs may also vary in surface characteristics, such as smooth or serrated surface. Serrated posts have lower rigidity than smooth posts. ${ }^{65}$ The structural characteristic and mechanical properties of fiber glass posts are manufacture-dependent. When analysing several fiberglass post evaluable on the marked place, a linear correlation between flexural strength and fiber/matrix ratio, as well as the flexural modulus and the amount of fiber was found. ${ }^{66}$ Thus, the addition of a serrated process on the post surface for the purpose of retention, could decrease the values of the post's flexural strength due to the discontinuous fibers ${ }^{6,67}$ (Figure 3).

b. Post length

The literature suggest that the post length should be two thirds of the tooth remnant total length or at least the crown length. This principle was created for the metallic endodontic posts that are retained in the root canal by friction. Although this principle should be considered for every rehabilitation with endodontic post sometimes the post length may be limited by root curvatures or an obstruction in the root canal. Glass fiber posts have the advantage of bonding to tooth structures trough adhesive systems and resin cements and therefore are less sensitive compared to the metallic posts. Studies that evaluated the stress distributions of endodontically treated teeth restored with glass fiber posts showed that the glass fiber posts were not significantly affected by the post length. ${ }^{14,15}$ However, the principle of the post length calculation described should be always considered by the clinicians because the preparation of the two-thirds of the root canal will increase the bonding surface, allowing better retention for the fiber glass post. ${ }^{68,69}$

c. Post diameter

Endodontically-treated teeth can be significantly weakened with canals that are flared by the progression of caries in combination with endodontic access and/or overpreparation. ${ }^{70}$ Restoration of such 


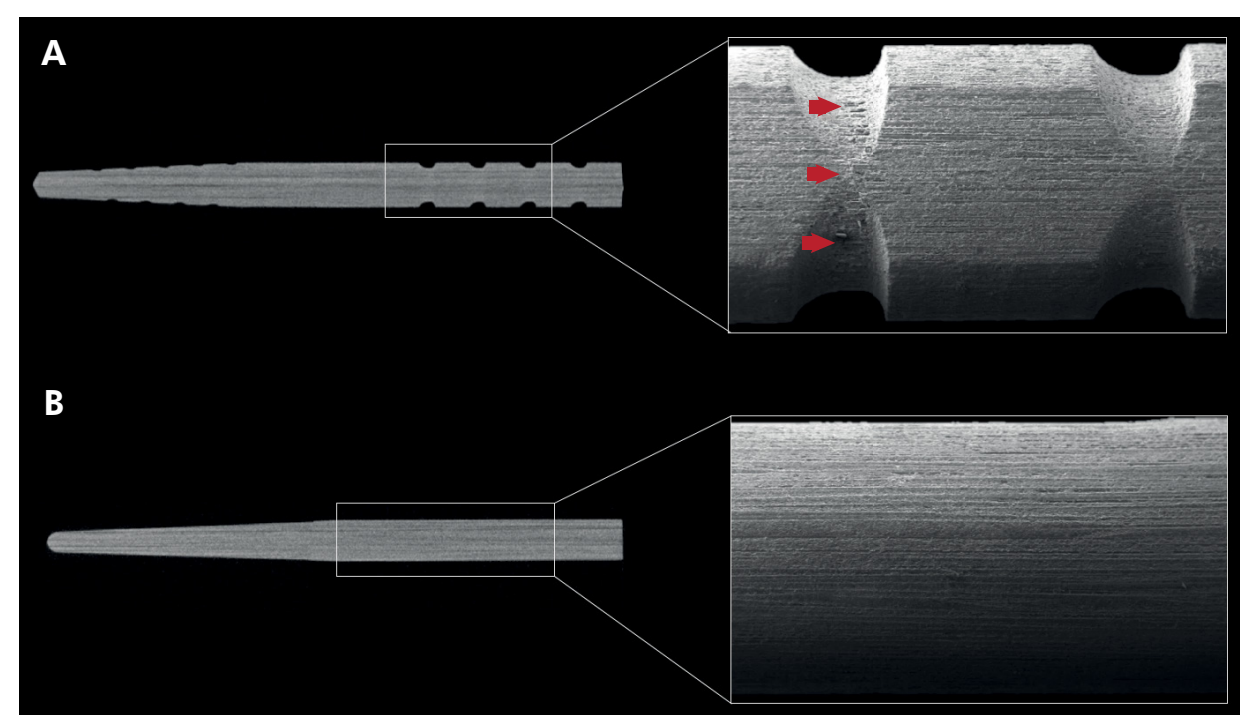

Figure 3. A. Serrated fiberglass post demonstrating the fracture line located caused by cutting of the fibers on the industrially produced post retention; B. Smooth fiberglass post demonstrating perfect integrity of the fibers along the entire post.

severely weakened teeth is a challenge because they are more prone to fracture and fatigue. Fiber posts with suitable shapes for flared canals are not readily available. A standard geometry glass fiber post leaves excess space within the flared root canal to be filled with a bulk of luting cement. This results in a potentially weak area, which may compromise the long-term prognosis. ${ }^{70}$ A simple alternative method is to reline glass fiber posts with composite resin. ${ }^{69,71}$ This anatomic post reduces the volume of luting cement and fits better to the canal wall (Figure 4). Because composite resin has an elastic modulus close to dentin, it creates a homogeneous stress distribution between the anatomical composite post and dentin surface that is similar to a sound tooth. ${ }^{14,70}$ Anatomical posts relined with composite resin resulted in the highest fracture resistance compared with other methods. ${ }^{70}$ d. Quantity and quality of the remaining coronal dentin (ferrule effect).

Several studies have shown that the amount and the quality of the remaining coronal dentin structure can affect the biomechanical behavior of the endodontically treated teeth restored with posts. The height of the remaining coronal dentin is well known as ferrule, and offers support to the remaining coronal tooth structure against occlusal loadings and lateral forces exerted during the post insertion. Studies have shown that the maintenance of 1.5 to $2 \mathrm{~mm}$ improve the stress distributions in the root dentin and along the post-dentin interface. ${ }^{14,15,16}$ The presence of the ferrule also contributes to increase the fracture resistance and better failure or fracture modes. Computational and in-vitro analysis showed that a circumferential or uniform ferrule creates a better stress distribution to the root dentin and post interface. A recent study, evaluated the effect of the non-uniform ferrule on the stress distribution using a patient-specific finite element analysis. ${ }^{13}$ The results of the stress analysis confirmed that the ferrule design play a significant role in the stress development with glass fiber posts and root dentin. The stress results also showed that the uniform ferrule tends to be more favorable than a localized higher ferrule in anterior endodontic-treated teeth (Figure 5). The literature shows that conservation of the tooth structure is the most important parameter to improve the biomechanical behavior of the endodontically treated teeth rehabilitated with glass fiber posts.

The correct choice of the post system and the presence of a ferrule are important factors for treatment prognosis. The presence of a ferrule on anterior endodontically treated incisors restored with a fiberglass post/composite core/CAD/ CAM ceramic 

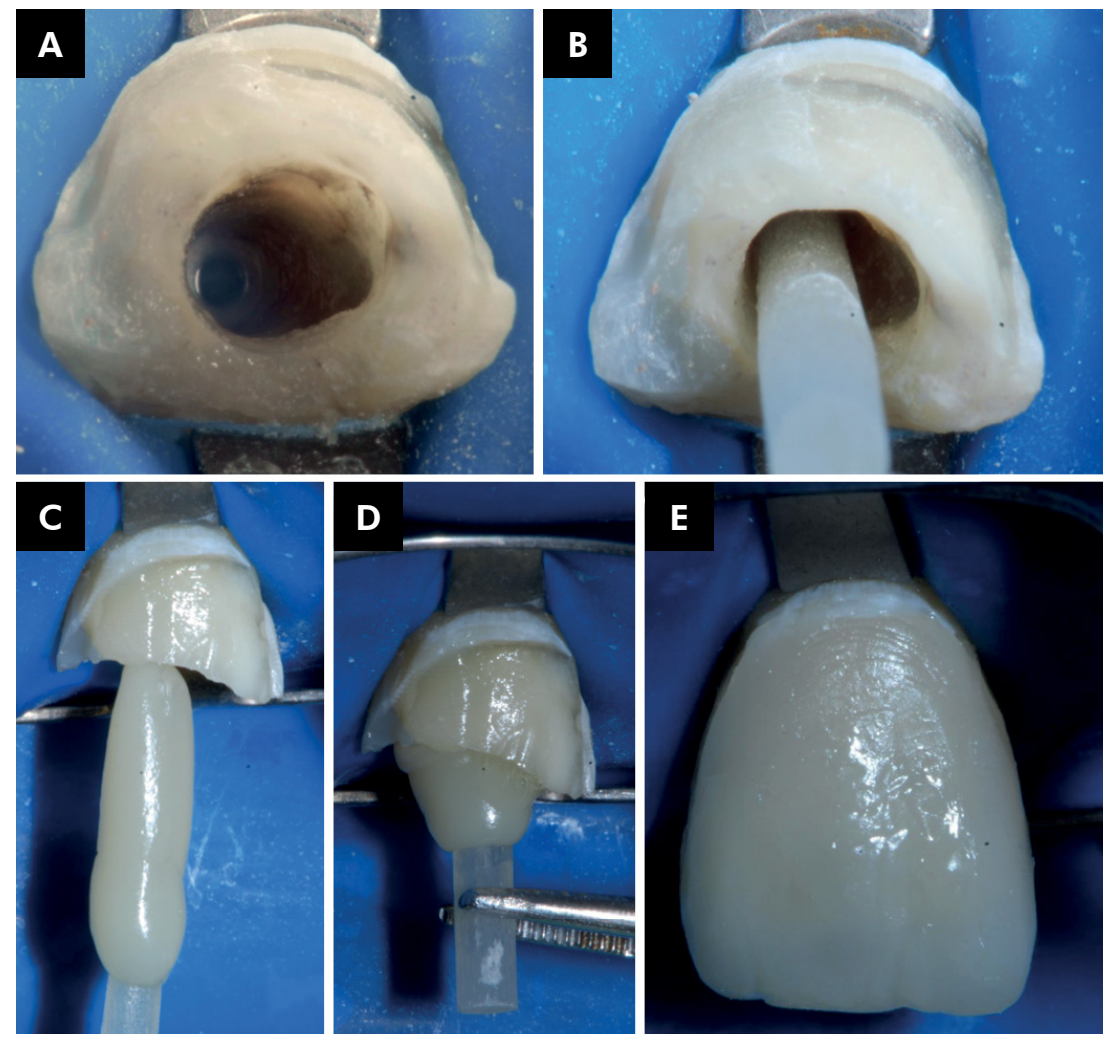

Figure 4. A. Flared root canal prepared to receive a fiber post; B. Note that the shape and diameter of post-hole is non-uniform, resulting in a mismatch between the fiber post and root canal walls; C. Relining procedure with composite resin; D Significant volume of composite covering the fiber post; E. Final direct composite restoration. In the absence of post relining, all this volume will be filled with resin cement during the cementation procedure.

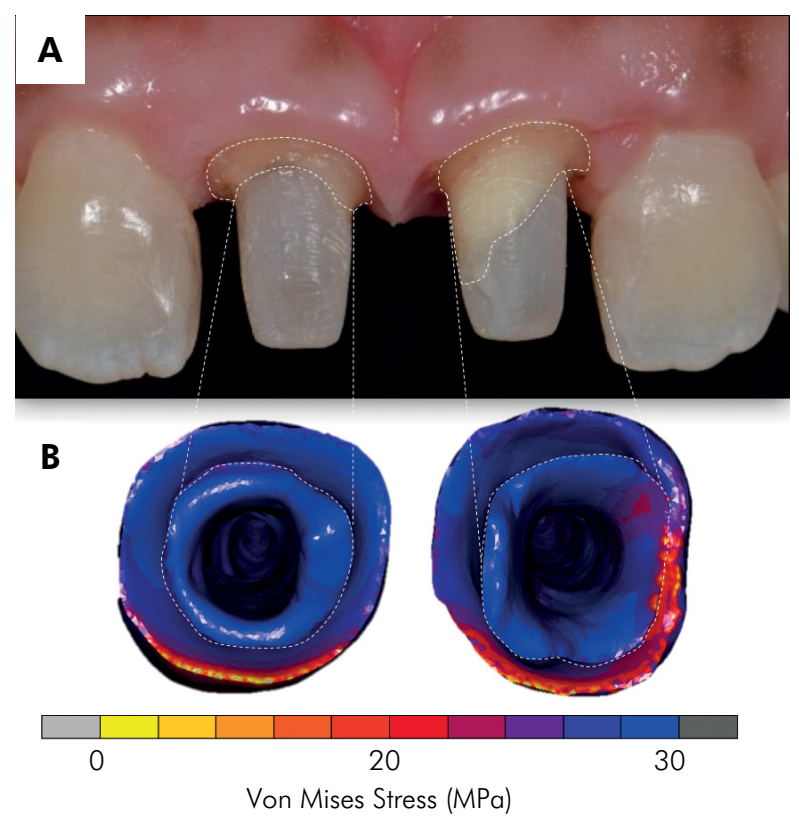

Figure 5. A. Central incisors with height and shape of ferrule presence; $B$. The stress distribution at the intracanal surface of the root dentin, showing that higher stress is found on area with shorter ferrule. crown influences reduce the stress concentration in root dentin, increase the fracture resistance and the reduction in number of root fractures. The ferrule presence is important for stress/strain transfer from the crown to root dentin. ${ }^{72}$

\section{Clinical performance of endodontic restorations}

Despite the importance of laboratorial studies assessing variables can intervene on performance of endodontic restorations, evidences to support clinical practice must be strongly based on clinical studies. Restoration of endodontically treated teeth remains a challenge for clinicians since these teeth are usually weakened due to significant loss of dentinal structure. In fact, practice-base studies evaluating huge number of restorations have confirmed the worse behavior of restorative procedures in non- 
vital teeth. A retrospective study evaluated the data from private clinics in Germany and assessed 795 restorations of endodontically treated teeth for an average follow-up time of 4.5 years. ${ }^{73}$ Approximately $86 \%$ of those restorations were considered successful and the annual failure rate (AFR) was $4.9 \%$. Interestingly, this AFR is slightly higher than that observed for restoration in vital teeth from patients with high- and medium-risk to caries after 5 years of function $(3.2 \%$ and $3.5 \%$, respectively), and around 4 -fold higher than AFR of restorations in patients with low-risk to caries $(1.2 \%) .{ }^{74}$ However, higher values of AFR were described by a large retrospective practice-based study investigating the longevity of 400.000 direct restorations placed by several general dental practitioners in the Netherlands that also demonstrated higher AFR $(10.9 \%)$ for restorations of endodontically treated teeth than those built-up in vital teeth $(4.5 \%){ }^{75}$

Factors as the restorative material used, cusp coverage, and direct or indirect procedure also might affect the performance of endodontic restorations over the time. A retrospective cohort study evaluating 220 endodontically treated permanent molars found that composite restorations presented higher median survival time ( 4.3 years) than those built-up with amalgam (median of 3.0 years), but the more significant factor favoring the longevity of restorations was the amount of remaining tooth structure. ${ }^{76}$ Another prospective study found that $96 \%$ of indirect composite restorations with cusp coverage in molars $(n=84)$ and premolars $(n=66)$ remained satisfactory after 5 years, ${ }^{77}$ suggesting an improved performance of this approach over intra-coronal restorations. However, lack evidence to support any superiority of indirect restorations over the direct ones. A systematic review ${ }^{78}$ tried to respond this question, but only a single study ${ }^{79}$ fully attended the inclusion criteria and was analyzed. The results of this included study did not demonstrate any difference between these two restorative approaches, and the level of evidence was low (only 104 teeth analyzed).

A controversial matter about restoration of endodontically treated teeth regards the placement or not of posts into the root canal to bear the restoration. It seems well-established that posts are required in the absence of remaining crown structure enough to retain the restoration, but it is difficult to determine the threshold after the post placement is not more required. An observational retrospective study evaluating 985 fiber post-retained restorations for 7-11 years also found that the lack of remaining coronal structure favors the failure of restoration ${ }^{80}$. Similar results were observed in a randomized controlled clinical trial with 6 years of follow-up. ${ }^{81}$ The presence of ferrule has been pointed by laboratorial studies and finite element analysis as an important factor increasing the fracture resistance of post-retained restorations. ${ }^{82,83,84}$ However, it is such difficult to measure and standardize the ferrule effect in clinical trials and controversial results can be observed.

A recently published meta-analysis evaluating any possible protective effect of ferrule included only three randomized clinical trials since lack information were available in other studies, direct restorations were used (no ferrule effect is present per definition), or the follow-up were shorter than 5 years. ${ }^{85}$ Indeed, the presence of ferrule increased only slightly the successful rate $(98 \%$ versus $93 \%$ ) after 5 years of observation, but only a single study ${ }^{86}$ was used to estimate any possible protective effect of ferrule for longer follow-up time (17-years). This last study found that the ferrule increased the survival rate for prefabricated titanium posts associated to composite crowns. Therefore, there is weak evidence from clinical studies supporting the favorable effect of ferrule to increase the long-term restoration survival. It is important to emphasize that both posterior and anterior teeth were included in that meta-analysis and it has been known that differences on loading direction among the teeth intervene on stress distribution and failure. ${ }^{87}$ Moreover, several studies only divide the ferrule as present or absent, and information as incomplete ferrules involving only partially the circumference of teeth, or differences on height/ thickness of coronal remaining tissue is frequently lost in clinical trials. It was demonstrated that incomplete ferrule involving higher than $75 \%$ of tooth circumference could increase in $5 \%$ the successful rate of restoration. ${ }^{85}$

Another question regards whether the post placement increase or not the longevity of restorations. A randomized controlled trial (6 years of follow-up) found that the placement of fiber post can reduce the failure rate of premolars presenting only one 
or two remaining coronal walls and restored with single-unit metal-ceramic crowns. ${ }^{81}$ The authors also observed the same positive effect of post placement was also observed in the absence of ferrule, which resulted in low rates even for fiber post-retained restorations. Other randomized clinical trials also demonstrated higher successful rate for post-retained restorations. ${ }^{86,88,89,90}$ Contrarily, a practice-base study with clinicians in Germany found that the placement of post increased almost three times the AFR despite the absence of statistical difference. ${ }^{73}$ A possible explanation hypothesized by authors was that posts were usually placed in teeth with a higher level of coronal breakdown, which tends to have worst prognostic. In fact, the amount of tooth structure remaining in the coronal portion plays important role on clinical behavior of restoration and maybe the presence of a single thick remaining cavity wall can be enough to establish a protective effect in the restoration..$^{91,92}$ Therefore, the placement of post seems to improve the longevity of endodontic restorations only when the tooth presents lack of coronal remaining cavity walls or a full single crown is used over a cavity preparation presenting ferrule. ${ }^{85}$

Controversial discussion is also observed regarding whether cast post and core, pre-fabricated metallic or glass-fiber post present better clinical performance. Further to analysis of fracture resistance, several laboratorial studies have demonstrated more favorable fractures when fiber post are used..$^{93}$ However, a meta-analysis of clinical trials did not find any difference among the types of posts regards the survival rate, and ratios of catastrophic or non-catastrophic failure ${ }^{94}$ It is important to emphasize that several studies included in this meta-analysis presented significant risk to bias and high heterogeneity was calculated for all outcomes, resulting in weak evidence.
An alternative to post placement into root canals is the used of endocrowns bonded to dentin of pulpal chamber. A retrospective clinical study evaluated 137 endocrowns cemented into pulpal chamber of molars $(57 \%)$, premolars $(41 \%)$ or canines $(2 \%)$; and confectioned with a Lithium disilicate glass-ceramic $(85 \%)$, a hybrid ceramic $(12 \%)$ or indirect composite $(3 \%)^{95}$. After a mean follow-up of 44.7 months, the survival rate was $99 \%$ and the estimate by Kaplan-Meier was $98.8 \%$ after 10 years. This success rate is like those observed for post-retained restorations, demonstrating that endocrowns can be a suitable alternative to restore endodontically treated teeth, mainly for posterior teeth.

\section{Summary statement}

In this review paper, we demonstrated that the performance of endodontic treated teeth is strongly related to the biomechanics events involved during all the phases of the endodontic treatment. The correct selection and use of the mechanical and rotatory instruments are essential for preventing dentin damage during root canal preparation. The ferule presence associated with adequate bonding protocol are directly related with the clinical success of fiberglass post. Direct composite restoration can be a good alterantive for restoting endodontic treated teeth when coronal structure remaining is presented. This review shows how much progress has been made in the endodontic procedures taking into account biomechanics principles involving news rotatory instruments, irrigants, bonding procedures and fiberglass post that will continue to benefit clinicians and their patients.

\section{Acknowledments}

This study was supported by grants from FAPEMIG, CAPES and CNPq.

\section{References}

1. Versluis A, Versluis-Tantbirojn D. Filling cavities or restoring teeth? J Tenn Dent Assoc. 2011;91(2):36-42.

2. Eltit $F$, Ebacher $V$, Wang R. Inelastic deformation and microcracking process in human dentin. J Struct Biol. 2013 Aug;183(2):141-8. https://doi.org/10.1016/i.jsb.2013.04.002

\author{
3. Salehrabi R, Rotstein I. Endodontic treatment \\ outcomes in a large patient population in \\ the USA: an epidemiological study. \\ J Endod. 2004 Dec;30(12):846-50. \\ https://doi.org/10.1097/01.don.0000145031.04236.ca
}


How biomechanics can affect the endodontic treated teeth and their restorative procedures?

4. Siqueira JF Jr. Aetiology of root canal treatment failure: why well-treated teeth can fail. Int Endod J. 2001 Jan;34(1):1-10. https://doi.org/10.1046/j.1365-2591.2001.00396.x

5. Grigoratos D, Knowles J, Ng YL, Gulabivala K. Effect of exposing dentine to sodium hypochlorite and calcium hydroxide on its flexural strength and elastic modulus. Int Endod J. 2001 Mar;34(2):113-9. https://doi.org/10.1046/i.1365-2591.2001.00356.x

6. Soares CJ, Santana FR, Silva NR, Preira JC, Pereira CA. Influence of the endodontic treatment on mechanical properties of root dentin. J Endod. 2007 May;33(5):603-6. https://doi.org/10.1016/i.joen.2007.01.016

7. Tang W, Wu Y, Smales RJ. Identifying and reducing risks for potential fractures in endodontically treated teeth. J Endod. 2010 Apr;36(4):609-17. https://doi.org/10.1016/i.joen.2009.12.002

8. Theodosopoulou JN, Chochlidakis KM. A systematic review of dowel (post) and core materials and systems. J Prosthodont. 2009 Aug; 18(6):464-72. https://doi.org/10.1111/j.1532-849X.2009.00472.x

9. Soares CJ, Valdivia AD, Silva GR, Santana FR, Menezes MS. Longitudinal clinical evaluation of post systems: a literature review. Braz Dent J. 2012;23(2):135-740. https://doi.org/10.1590/S0103-64402012000200008

10. Soares PV, Santos-Filho PC, Martins LR, Soares CJ. Influence of restorative technique on the biomechanical behavior of endodontically treated maxillary premolars. Part I: fracture resistance and fracture mode. J Prosthet Dent. 2008 Jan;99(1):30-7. https://doi.org/10.1016/S0022-3913(08)60006-2

11. Soares PV, Santos-Filho PC, Gomide HA, Araujo CA, Martins LR, Soares CJ. Influence of restorative technique on the biomechanical behavior of endodontically treated maxillary premolars. Part II: strain measurement and stress distribution. J Prosthet Dent. 2008 Feb;99(2):114-22. https://doi.org/10.1016/S0022-3913(08)60027-X

12. Pereira R, Bicalho AA, Franco SD, Tantbirojn D, Versluis A, Soares CJ. Effect of restorative protocol on cuspal strain and residual stress in endodontically treated molars. Oper Dent. 2016 Jan-Feb;41(1):23-33. https://doi.org/10.2341/14-178-L

13. Rodrigues MP, Soares PB, Valdivia AD, Pessoa RS, Veríssimo C, Versluis A et al. Patient-specific Finite Element Analysis of Fiber Post and Ferrule Design. J Endod. 2017 Sep;43(9):153944. https://doi.org/10.1016/i.joen.2017.04.024

14. Santos-Filho PC, Veríssimo C, Raposo LH, Noritomi MecEng PY, Marcondes Martins LR. Influence of ferrule, post system, and length on stress distribution of weakened root-filled teeth. J Endod. 2014 Nov;40(11):1874-8. https://doi.org/10.1016/i.joen.2014.07.015

15. Santos-Filho PC, Veríssimo C, Soares PV, Saltarelo RC, Soares CJ, Marcondes Martins LR. Influence of ferrule, post system, and length on biomechanical behavior of endodontically treated anterior teeth. J Endod. 2014 Jan;40(1):119-23. https://doi.org/10.1016/j.joen.2013.09.034
16. Veríssimo C, Simamoto Júnior PC, Soares CJ, Noritomi PY, Santos-Filho PC. Effect of the crown, post, and remaining coronal dentin on the biomechanical behavior of endodontically treated maxillary central incisors. J Prosthet Dent. 2014 Mar;111(3):234 46. https://doi.org/10.1016/i.prosdent.2013.07.006

17. Dablanca-Blanco AB, Blanco-Carrión J, Martín-Biedma B, Varela-Patiño P, Bello-Castro A, Castelo-Baz P. Management of large class II lesions in molars: how to restore and when to perform surgical crown lengthening? Restor Dent Endod. 2017 Aug;42(3):240-52. https://doi.org/10.5395/rde.2017.42.3.240

18. Khan J, Benoliel R, Herzberg U, Mannes AJ, Caudle RM, Young A, Eliav E. Bite force and pattern measurements for dental pain assessment in the rat. Neurosci Lett. 2008 Dec; 12;447(2-3):175-8. https://doi.org/10.1016/i.neulet.2008.10.008

19. Amade ES, Novais VR, Roscoe MG, Azevedo FM, Bicalho AA, Soares CJ. Root dentin strain and temperature rise during endodontic treatment and post rehabilitation. Braz Dent J. 2013 Nov-Dec;24(6):591-8. https://doi.org/10.1590/0103-6440201302268

20. Estrela C. Pécora JD, Estrela CRA, Guedes OA, Silva BSF, Soares CJ, Sousa-Neto MD. Common operative procedural errors and clinical factors associated with root canal treatment. Braz Dent J. 2017 Jan-Apr;28(2):179-90. https://doi.org/10.1590/0103-6440201702451

21. Miör IA. Human coronal dentine: structure and reactions. Oral Surg Oral Med Oral Pathol. 1972 May;33(5):810-23. https://doi.org/10.1016/0030-4220(72)90451-3

22. Giannini M, Soares CJ, Carvalho RM. Ultimate tensile strength of tooth structures. Dent Mater. 2004 May;20(4):3229. https://doi.org/10.1016/S0109-5641(03)00110-6

23. Lin CP, Douglas WH. Structure-property relations and crack resistance at the bovine dentin-enamel junction. J Dent Res. 1994 May;73(5):1072-8. https://doi.org/10.1177/00220345940730050901

24. Saleh AA, Ettman WM. Effect of endodontic irrigation solutions on microhardness of root canal dentine. J Dent. 1999 Jan;27(1):43-6. https://doi.org/10.1016/S0300-5712(98)00018-9

25. Tartari T, Bachmann L, Zancan RF, Vivan RR, Duarte MA, Bramante CM. Analysis of the effects of several decalcifying agents alone and in combination with sodium hypochlorite on the chemical composition of dentine. Int Endod J. 2018 Jan;51 Suppl 1:e42-54. https://doi.org/10.1111/iej.12764

26. Renovato SR, Santana FR, Ferreira JM, Souza JB, Soares CJ, Estrela C. Effect of calcium hydroxide and endodontic irrigants on fibre post bond strength to root canal dentine. Int Endod J. 2013 Aug;46(8):738-46. https://doi.org/10.1111/iej.12053

27. Kim HC, Cheung GS, Lee CJ, Kim BM, Park JK, Kang SI. Comparison of forces generated during root canal shaping and residual stresses of three nickel-titanium rotary files by using a three-dimensional finite-element analysis. J Endod. 2008 Jun;34(6):743-7. https://doi.org/10.1016/i.joen.2008.03.015 
28. Bier CA, Shemesh H, Tanomaru-Filho M, Wesselink PR, Wu MK. The ability of different nickel-titanium rotary instruments to induce dentinal damage during canal preparation. J Endod. 2009 Feb;35(2):236-8. https://doi.org/10.1016/j.joen.2008.10.021

29. Kim HC, Lee MH, Yum J, Versluis A, Lee CJ, Kim $B M$. Potential relationship between design of nickel-titanium rotary instruments and vertical root fracture. J Endod. 2010 Jul;36(7):1195-9. https://doi.org/10.1016/i.joen.2010.02.010

30. Schäfer E, Zandbiglari T, Schäfer J. Influence of resinbased adhesive root canal fillings on the resistance to fracture of endodontically treated roots: an in vitro preliminary study. Oral Surg Oral Med Oral Pathol Oral Radiol Endod. 2007 Feb;103(2):274-9. https://doi.org/10.1016/i.tripleo.2006.06.054

31. Adorno CG, Yoshioka T, Suda H. The effect of root preparation technique and instrumentation length on the development of apical root cracks. J Endod. 2009 Mar;35(3):389-92. https://doi.org/10.1016/i.joen.2008.12.008

32. Schäfer $E$, Lau R. Comparison of cutting efficiency and instrumentation of curved canals with nickel-titanium and stainless-steel instruments. J Endod. 1999 Jun;25(6):427-30. https://doi.org/10.1016/S0099-2399(99)80272-6

33. Cheung GS, Liu CS. A retrospective study of endodontic treatment outcome between nickeltitanium rotary and stainless steel hand filing techniques. J Endod. 2009 Jul;35(7):938-43. https://doi.org/10.1016/j.joen.2009.04.016

34. Blum JY, Cohen A, Machtou P, Micallef JP. Analysis of forces developed during mechanical preparation of extracted teeth using Profile NiTi rotary instruments. Int Endod J. 1999 Jan;32(1):24-31. https://doi.org/10.1111/j.1365-2591.1999.tb01408.x

35. Ha JH, Cheung GS, Versluis A, Lee CJ, Kwak SW, Kim HC. 'Screw-in' tendency of rotary nickel-titanium files due to design geometry. Int Endod J. 2015 Jul;48(7):666-72. https://doi.org/10.1111/iej.12363

36. Ha JH, Kwak SW, Kim SK, Kim HC. Screw-in forces during instrumentation by various file systems. Restor Dent Endod. 2016 Nov; 41 (4):304-9. https://doi.org/10.5395/rde.2016.41.4.304

37. Tamse A, Fuss Z, Lustig J, Kaplavi J. An evaluation of endodontically treated vertically fractured teeth. J Endod. 1999 Jul;25(7):506-8. https://doi.org/10.1016/S0099-2399(99)80292-1

38. Fuss Z, Lustig J, Katz A, Tamse A. An evaluation of endodontically treated vertical root fractured teeth: impact of operative procedures. J Endod. 2001 Jan;27(1):46-8. https://doi.org/10.1097/00004770-200101000-00017

39. Vire DE. Failure of endodontically treated teeth: classification and evaluation. J Endod. 1991 Jul;17(7):338-42. https://doi.org/10.1016/S0099-2399(06)81702-4
40. Arslan H, Karataş E, Capar ID, Ozsu D, Doğanay E. Effect of ProTaper Universal, Endoflare, Revo-S, HyFlex coronal flaring instruments, and Gates Glidden drills on crack formation. J Endod. 2014 Oct;40(10):1681-3. https://doi.org/10.1016/j.joen.2014.06.004

41. Yared G. Canal preparation using only one $\mathrm{Ni}$ Ti rotary instrument: preliminary observations. Int Endod J. 2008 Apr;41(4):339 44. https://doi.org/10.1111/i.1365-2591.2007.01351.x

42. Kim HC, Kwak SW, Cheung GS, Ko DH, Chung SM, Lee W. Cyclic fatigue and torsional resistance of two new nickel-titanium instruments used in reciprocation motion: reciproc versus WaveOne. J Endod. 2012 Apr;38(4):541-4. https://doi.org/10.1016/i.joen.2011.11.014

43. Shin CS, Huang YH, Chi CW, Lin CP. Fatigue life enhancement of NiTi rotary endodontic instruments by progressive reciprocating operation. Int Endod J. 2014 Sep;47(9):882-8. https://doi.org/10.1111/iej.12233

44. Bürklein S, Tsotsis $P$, Schäfer E. Incidence of dentinal defects after root canal preparation: reciprocating versus rotary instrumentation. J Endod. 2013 Apr;39(4):501-4. https://doi.org/10.1016/i.joen.2012.11.045

45. Abou El Nasr HM, Abd El Kader KG. Dentinal damage and fracture resistance of oval roots prepared with single-file systems using different kinematics. J Endod. 2014 Jun;40(6):849-51. https://doi.org/10.1016/i.joen.2013.09.020

46. De-Deus G, Silva EJ, Marins J, Souza E, Neves AA, Gonçalves Belladonna F, et al. Lack of causal relationship between dentinal microcracks and root canal preparation with reciprocation systems. J Endod. 2014 Sep;40(9):1447-50. https://doi.org/10.1016/i.joen.2014.02.019

47. Ahn SY, Kim HC, Kim E. Kinematic effects of nickel-titanium instruments with reciprocating or continuous rotation motion: a systematic review of in vitro studies. J Endod. $2016 \mathrm{Jul} ; 42(7): 1009-17$. https://doi.org/10.1016/i.joen.2016.04.002

48. Ashwinkumar V, Krithikadatta J, Surendran S, Velmurugan N. Effect of reciprocating file motion on microcrack formation in root canals: an SEM study. Int Endod J. 2014 Jul;47(7):622-7. https://doi.org/10.1111/iej.12197

49. Shen Y, Zhou HM, Zheng YF, Peng B, Haapasalo M. Current challenges and concepts of the thermomechanical treatment of nickel-titanium instruments. J Endod. 2013 Feb;39(2):16372. https://doi.org/10.1016/i.joen.2012.11.005

50. Goo HJ, Kwak SW, Ha JH, Pedullà E, Kim HC. Mechanical properties of various heat-treated nickel-titanium rotary instruments. J Endod. $2017 \mathrm{Nov}$;43(11):1872-7. https://doi.org/10.1016/i.joen.2017.05.025

51. Yoldas O, Yilmaz S, Atakan G, Kuden C, Kasan Z. Dentinal microcrack formation during root canal preparations by different NiTi rotary instruments and the self-adjusting file. J Endod. 2012 Feb;38(2):232-5. https://doi.org/10.1016/i.joen.2011.10.011 
52. Liu R, Hou BX, Wesselink PR, Wu MK, Shemesh $\mathrm{H}$. The incidence of root microcracks caused by 3 different single-file systems versus the ProTaper system. J Endod. 2013 Aug;39(8):1054-6. https://doi.org/10.1016/i.joen.2013.04.013

53. Kim HC, Sung SY, Ha JH, Solomonov M, Lee $J M$, Lee $C J$ et al. Stress generation during selfadjusting file movement: minimally invasive instrumentation. J Endod. 2013 Dec;39(12):1572-5. https://doi.org/10.1016/i.joen.2013.07.021

54. Lacerda MF, Marceliano-Alves MF. Pérez AR, Provenzano JC, Neves MAS, Pires FR et al. Cleaning and shaping oval canals with instrumentation systems: a correlative micro-computed tomographic and histologic study. J Endod. 2017 Nov;43(11):1878-84. https://doi.org/10.1016/j.joen.2017.06.032

55. Silva EJ, Vieira VT, Belladonna FG, Zuolo AS, Antunes HD, Cavalcante DM, et al. Cyclic and Torsional Fatigue Resistance of XP-endo Shaper and TRUShape Instruments. J Endod. 2018 Jan;44(1):168-72. https://doi.org/10.1016/i.joen.2017.08.033

56. Zuolo ML, Zaia AA, Belladonna FG, Silva EJ, Souza EM, Versiani MA et al. Micro-CT assessment of the shaping ability of four root canal instrumentation systems in ovalshaped canals. Int Endod J. 2018 May 51(5):564-71. https://doi.org/10.1111/iej.12810

57. Bayram HM, Bayram E, Ocak M, Uzuner MB, Geneci F, Celik HH. Micro-computed tomographic evaluation of dentinal microcrack formation after using new heat-treated nickel-titanium systems. J Endod. 2017 Oct;43(10):1736-9. https://doi.org/10.1016/j.joen.2017.05.024

58. Shemesh H, Cristescu RC, Wesselink PR, Wu MK. The use of cone-beam computed tomography and digital periapical radiographs to diagnose root perforations. J Endod. 2011 Apr;37(4):513-6. https://doi.org/10.1016/i.joen.2010.12.003

59. Pereira RD, Valdívia AD, Bicalho AA, Franco SD, Tantbirojn $D$, Versluis $A$ et al. Effect of Photoactivation Timing on the Mechanical Properties of Resin Cements and Bond Strength of Fiberglass Post to Root Dentin. Oper Dent. 2015 SepOct;40(5):E206-21. https://doi.org/10.2341/14-115-L

60. Schliebe LRO, Braga SSL, Pereira RAS, Bicalho AA, Veríssimo C, Novais VR et al. The new generation of conventional and bulk-fill composites do not reduce the shrinkage stress in endodonticallytreated molars. Am J Dent. 2016 Dec;29(6):333-8.

61. Soares CJ, Rodrigues MP, Oliveira LR, Braga SS, Barcelos LM, Silva GR et al. An evaluation of the light output from 22 contemporary light curing units. Braz Dent J. 2017 May-Jun;28(3):362-71. https://doi.org/10.1590/0103-6440201601466

62. Silva ALF, Casselli DS, Ambrosano GM, Martins LR. Effect of the adhesive application mode and fiber post translucency on the push-out bond strength to dentin. J Endod. 2007 Sep;33(9):1078-81. https://doi.org/10.1016/i.joen.2007.03.018
63. Price RB, Strassler HE, Price HL, Seth S, Lee CJ. The effectiveness of using a patient simulator to teach lightcuring skills. J Am Dent Assoc. 2014 Jan;145(1):32-43. https://doi.org/10.14219/jada.2013.17

64. Goracci C, Ferrari M. Current perspectives on post systems: a literature review. Aust Dent J. 2011 Jun;56 Suppl 1:77-83. https://doi.org/10.1111/j.1834-7819.2010.01298.x

65. Menezes MS, Queiroz EC, Soares PV, Faria-e-Silva AL, Soares CJ, Martins LR. Fiber post etching with hydrogen peroxide: effect of concentration and application time. J Endod. 2011 Mar;37(3):398-402. https://doi.org/10.1016/i.joen.2010.11.037

66. Novais VR, Rodrigues RB, Simamoto Júnior PC, Lourenço CS, Soares CJ. Correlation between the Mechanical Properties and Structural Characteristics of Different Fiber Posts Systems. Braz Dent J. 2016 Jan-Feb;27(1):46-51. https://doi.org/10.1590/0103-6440201600377

67. Göhring TN, Peters OA. Restoration of endodontically treated teeth without posts. Am J Dent. 2003 Oct;16(5):313-7.

68. Macedo VC, Souza NA, Faria e Silva AL, Cotes C, da Silva C, Martinelli $M$, et al. Pullout bond strength of fiber posts luted to different depths and submitted to artificial aging. Oper Dent. 2013 Jul-Aug;38(4):E1-6. https://doi.org/10.2341/12-321-L

69. Macedo VC, Silva ALF, Martins LR. Effect of cement type, relining procedure, and length of cementation on pull-out bond strength of fiber posts. J Endod. 2010 Sep;36(9):15436. https://doi.org/10.1016/i.joen.2010.04.014

70. Silva GR, Santos-Filho PC, Simamoto-Júnior PC, Martins LR, Mota AS, Soares CJ. Effect of post type and restorative techniques on the strain and fracture resistance of flared incisor roots. Braz Dent J. 2011;22(3):230-7. https://doi.org/10.1590/S0103-64402011000300009

71. Faria-e-Silva AL, Pedrosa-Filho CF, Menezes MS, Silveira DM, Martins LR. Effect of relining on fiber post retention to root canal. J Appl Oral Sci. 2009 Nov-Dec;17(6):600-4. https://doi.org/10.1590/S1678-77572009000600012

72. Valdivia AD, Rodrigues MP, Bicalho AA, Van Meerbeek B, Sloten $J V$, Pessoa RS et al. Biomechanical effect of ferrule on incisors restored with a fiberglass post and lithium-disilicate ceramic crown after thermal cycling and fatigue loading. J Adhes Dent. 2018 Apr;20:1-10. https://doi.org/10.3290/i.jad.a40305

73. Skupien JA, Opdam N, Winnen R, Bronkhorst E, Kreulen C, Pereira-Cenci $T$, et al. A practice-based study on the survival of restored endodontically treated teeth. J Endod. 2013 Nov;39(11):1335-40. https://doi.org/10.1016/i.joen.2013.06.028

74. Opdam NJ, van de Sande FH, Bronkhorst E, Cenci MS, Bottenberg P, Pallesen $U$, et al. Longevity of posterior composite restorations: a systematic review and meta-analysis. J Dent Res. 2014 Oct;93(10):943-9. https://doi.org/10.1177/0022034514544217

75. Laske M, Opdam NJ, Bronkhorst EM, Braspenning JC, Huysmans MC. Longevity of direct restorations in Dutch dental practices. Descriptive study out of a practice based research network. J Dent. 2016 Mar;46:12-7. https://doi.org/10.1016/i.jdent.2016.01.002 
76. Nagasiri R, Chitmongkolsuk S. Long-term survival of endodontically treated molars without crown coverage: a retrospective cohort study. J Prosthet Dent. 2005 Feb;93(2):16470. https://doi.org/10.1016/i.prosdent.2004.11.001

77. Dias MC, Martins JN, Chen A, Quaresma SA, Luís H, Caramês J. Prognosis of indirect composite resin cuspal coverage on endodontically treated premolars and molars: an in vivo prospective study. J Prosthodont. 2016 Sep. https://doi.org/10.1111/jopr.12545

78. Sequeira-Byron P, Fedorowicz Z, Carter B, Nasser M, Alrowaili $E F$. Single crowns versus conventional fillings for the restoration of root-filled teeth. Cochrane Database Syst Rev. 2015 Sep 25;(9). https://doi.org/10.1002/14651858.CD009109.pub3

79. Mannocci F, Bertelli E, Sherriff M, Watson TF, Pitt Ford TR. Three-year clinical comparison of survival of endodontically treated teeth restored with either full cast coverage or with direct composite restoration. 2002. Int Endod J. 2009 May;42(5):401-5. https://doi.org/10.1111/j.1365-2591.2009.01559.x

80. Ferrari M, Cagidiaco MC, Goracci C, Vichi A, Mason PN, Radovic I, et al. Long-term retrospective study of the clinical performance of fiber posts. Am J Dent. 2007 Oct;20(5):287-91.

81. Ferrari M, Vichi A, Fadda GM, Cagidiaco MC, Tay FR, Breschi $L$ et al. A randomized controlled trial of endodontically treated and restored premolars. J Dent Res. 2012 Jul;91(7 Suppl):72S-8S. https://doi.org/10.1177/0022034512447949

82. da Silva NR, Raposo LH, Versluis A, FernandesNeto AJ, Soares CJ. The effect of post, core, crown type, and ferrule presence on the biomechanical behavior of endodontically treated bovine anterior teeth. J Prosthet Dent. 2010 Nov; 104(5):306-17. https://doi.org/10.1016/S0022-3913(10)60146-1

83. Roscoe MG, Noritomi PY, Novais VR, Soares CJ. Influence of alveolar bone loss, post type, and ferrule presence on the biomechanical behavior of endodontically treated maxillary canines: strain measurement and stress distribution. J Prosthet Dent. 2013 Aug;110(2):116-26. https://doi.org/10.1016/S0022-3913(13)60350-9

84. Ausiello P, Ciaramella S, Martorelli M, Lanzotti A, Zarone $F$, Watts DC et al. Mechanical behavior of endodontically restored canine teeth: effects of ferrule, post material and shape. Dent Mater. 2017 Dec;33(12):1466-72. https://doi.org/10.1016/i.dental.2017.10.009

85. Naumann M, Schmitter M, Frankenberger R, Krastl G. "Ferrule Comes First. Post Is Second!" Fake News and alternative facts? A systematic review. J Endod. 2018 Feb;44(2):212-9. https://doi.org/10.1016/i.joen.2017.09.020
86. Fokkinga WA, Kreulen CM, Bronkhorst EM, Creugers NH. Composite resin core-crown reconstructions: an up to 17-year follow-up of a controlled clinical trial. Int J Prosthodont. 2008 Mar-Apr;21(2):109-15.

87. Castro CG, Santana FR, Roscoe MG, Simamoto Junior PC, Santos-Filho PC, Soares CJ. Fracture resistance and mode of failure of various types of root filled teeth. Int Endod J. 2012 Sep;45(9):840-7. https://doi.org/10.1111/j.1365-2591.2012.02041.x

88. Creugers NH, Kreulen CM, Fokkinga WA, Mentink AG. A 5 -year prospective clinical study on core restorations without covering crowns. Int J Prosthodont. 2005 Jan-Feb;18(1):40-1.

89. Fokkinga WA, Kreulen CM, Bronkhorst EM, Creugers NH. Up to 17-year controlled clinical study on post-and-cores and covering crowns. J Dent. 2007 Oct;35(10):778-86. https://doi.org/10.1016/i.jdent.2007.07.006

90. Cloet $E$, Debels $E$, Naert I. Controlled clinical trial on the outcome of glass fiber composite cores versus wrought posts and cast cores for the restoration of endodontically treated teeth: a 5-year follow-up study. Int J Prosthodont. 2017 Jan/ Feb;30(1):71-9. https://doi.org/10.11607/iip.4861

91. Bitter K, Noetzel J, Stamm O, Vaudt J, Meyer-Lueckel H, Neumann $\mathrm{K}$ et al. Randomized clinical trial comparing the effects of post placement on failure rate of postendodontic restorations: preliminary results of a mean period of 32 months. J Endod. 2009 Nov;35(11):1477-82. https://doi.org/10.1016/i.joen.2009.07.026

92. Sorrentino R, Di Mauro MI, Ferrari M, Leone R, Zarone F. Complications of endodontically treated teeth restored with fiber posts and single crowns or fixed dental prostheses-a systematic review. Clin Oral Investig. 2016 Sep;20(7):144957. https://doi.org/10.1007/s00784-016-1919-8

93. Zhou $L$, Wang $Q$. Comparison of fracture resistance between cast posts and fiber posts: a metaanalysis of literature. J Endod. 2013 Jan;39(1):11-5. https://doi.org/10.1016/i.joen.2012.09.026

94. Figueiredo FE, Martins-Filho PR, Faria-E-Silva AL. Do metal post-retained restorations result in more root fractures than fiber post-retained restorations? A systematic review and meta-analysis. J Endod. 2015 Mar;41(3):309-16. https://doi.org/10.1016/i.joen.2014.10.006

95. Belleflamme MM, Geerts SO, Louwette MM, Grenade CF, Vanheusden AJ, Mainjot AK. No post-no core approach to restore severely damaged posterior teeth: an up to 10-year retrospective study of documented endocrown cases. J Dent. 2017 Aug;63:1-7. https://doi.org/10.1016/i.jdent.2017.04.009 